\title{
Profile of Junior High School Students' Constraints in Online Science Learning
}

\author{
Desy Suryani $^{1}$, Eko Hariyono ${ }^{2}$, Tjipto Prastowo ${ }^{3}$ \\ 1,2 Science Education Study Program, Postgraduate Program, Universitas Negeri Surabaya, Surabaya, Indonesia \\ ${ }^{3}$ Physics Department, Universitas Negeri Surabaya, Surabaya, Indonesia
}

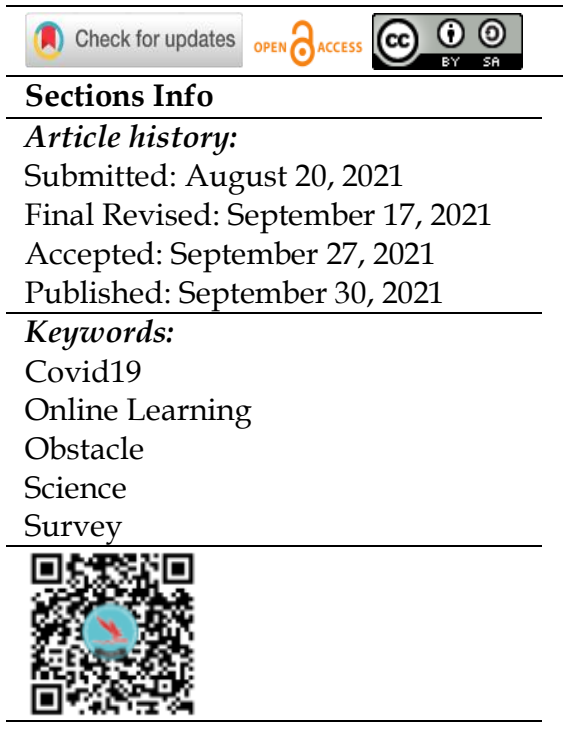

DOI : $\underline{\text { https:// doi.org/10.46245/ijorer.v2i5.153 }}$

\section{INTRODUCTION}

Nowdays, we face a different way in live. In 2020, the whole world underwent massive changes due to the emergence of the Covid19 virus which was discovered in Wuhan, China at the end of 2019 (Onyema et al., 2020). This virus causes the failure of the human respiratory system and spreads so fast, it can even cause death. Until now, there is no definite information about where the virus came from. Every country chooses to do lockdown and social distancing to avoid the spread of the virus. This decision caused various sectors to be paralyzed, including the education sector (Wijaya et al., 2020).

As of 29 June 2020, more than one billion students, or $61 \%$ of the global student population, were affected by school closures (UNESCO, 2020). Schools have been forced to stop face-to-face sessions in class and are gradually shifting to online learning. In Indonesia, the Ministry of Education and Culture on March 24, 2020 issued Circular No. 4 of 2020 concerning the Implementation of Education Policies in the Emergency Period for the Spread of Coronavirus Disease (Covid-19), one of which states that learning activities are carried out from home through online learning to provide meaningful learning experiences to students and complete learning objectives. Teachers who are accustomed to face-to-face lectures in class need to adapt to online learning that can be done synchronously or asynchronously (Landicho, 2021).

Online learning is one form of learning method by using the internet, that can increase the role of students in the learning process (Saifuddin, 2018). Several institutions have experimented with online learning systems such as e-learning before the pandemic. Based on this, there are several benefits of online learning, such as 
convenience, flexibility, time saving, teamwork, and the opportunity to collaborate with others without the limitations of space and time (Hung et al., 2010). Online learning also offers opportunities to maximize Internet resources, expand students' knowledge, and not limited by place or time (Gilbert, 2015). In addition, students can have more control over their learning activities and make decisions on their homework with more flexibility (Rafique et al., 2021). Rosdiana et al (2018) stated that learning vibrations and waves by applying online learning is more optimal for improving problem solving and graphing skills of prospective science teachers. However, when the online system is carried out massively like the current pandemic, it can actually cause various obstacles.

Science education is one of the subjects in junior high school which is an important foundation for forming quality human resources (Rusilowati et al., 2016). Science education is one aspect of education that uses science as a tool to achieve educational goals, especially the goals of science education. Learning science is an ideal way to gain competence (skills, maintain attitudes, and develop mastery of concepts related to everyday experience) (Ali, 2018). Willy nilly, the delivery of these subjects must also be delivered online to students, without reducing its essence. The adjustment of this learning system must be considered carefully, so that learning can run well. The most important thing in implementing online learning for students is to pay attention to various aspects so that learning objectives are achieved (Abidin and Arizona, 2020). For students and even parents, online learning means turning their personal space at home into a study and work space. Most classroom activities will be conducted online, communication and interaction will occur on platforms such as virtual classrooms, discussion boards online, and video conferencing. Moreover, in online learning, both teachers and students must have to engage in online platforms (Arnaud, 2020).

It is undeniable that online learning is the best solution for an unprecedented situation, such as the pandemic situation we are currently facing. However, this research has several drawbacks. Chung et al (2020), say that with online learning, students cannot interact directly, or the level of social involvement that a person experiences while in class does not occur. These challenges can cause students to feel that something is missing, and result in decreased student engagement and interaction with the resulting substandard learning experience.

The readiness of human resources including teachers, students, and parental support is the most important part in the implementation of online learning. Previous research conducted in West Java (Fauzi and Khusuma, 2020), 73.9\% of teachers stated that online learning was not effective. Teachers find many problems when carrying out teaching and learning activities using online learning systems. These problems include (1) school facilities; (2) internet connection; (3) planning, implementation and evaluation of teaching and learning activities. It can be said that teachers are still not ready with the current conditions, and when it comes to conducting online teaching and learning activities during the pandemic. Then, how do students's view about the online learning system? Do they also experience problems while learning? Of course yes. Therefore, the researcher intends to conduct research on students' views on online science learning.

\section{RESEARCH METHOD General Background}

This research uses a descriptive approach with a survey method that aims to describe the circumstances or phenomena that occur (Arikunto, 2010). Sudjana stated that 
descriptive research is a test that is carried out in stages where the researcher describes one or more symptoms, cases, cases that are currently happening, takes problems or focuses on actual problems (Sudjana, 2012).

\section{Sample / Participants / Group}

This research was conducted to obtain exploratory data on students' views in the implementation of online science learning. The research respondents were junior high school students/equivalent in Nganjuk.

\section{Instrument and Procedures}

The survey was conducted online via google form. Survey research is research that takes a sample from one population and uses a questionnaire as the main data collection tool (Adiyanta, 2019). As many as 70 students have been recorded as respondents in this research.

\section{Data Analysis}

The survey using a closed questionnaire method. However, there is one question that gives freedom to respond or respond. Furthermore, the research data were analyzed using descriptive quantitative analysis of the percentage technique directly from the google form.

\section{RESULTS AND DISCUSSION}

The results showed that since the beginning of the new academic year 2020/2021, public and private junior high schools have started to implement online learning. As stated by the Ministry of Education and Culture in circular letter No. 4 of 2020 which contains instructions for learning required from home or online. Based on the survey results, as many as $65.7 \%$ of students feel online learning science is boring and does not help them in learning the material. Pavlovic et al (2015) from his research stated that students have a perception that online learning is something that is boring and burdensome for them.

\section{What do you think about online learning?}

70 responses

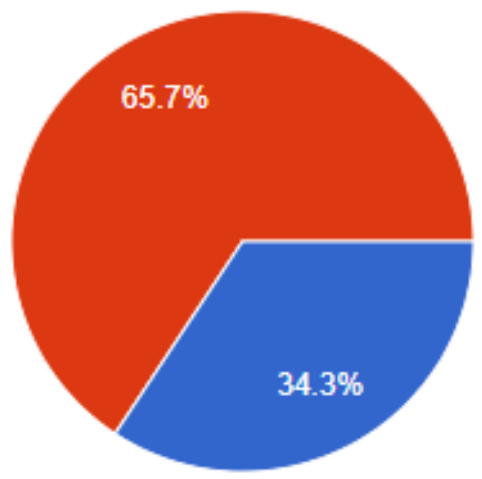

Fun

Bored

Figure 1. Results of the survey of students' perceptions of science online learning. 


\section{Does the online learning process help you understand the material?}

70 responses

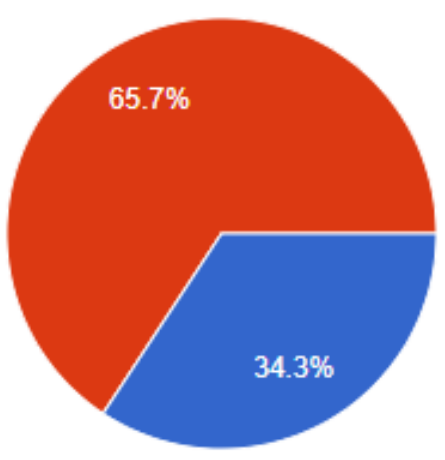

Yes

No

Figure 2. Results of the survey of students' perceptions of science online learning.

Based on the data obtained from the questionnaire, the obstacles faced during online learning of science for junior high school students in Nganjuk are as follows

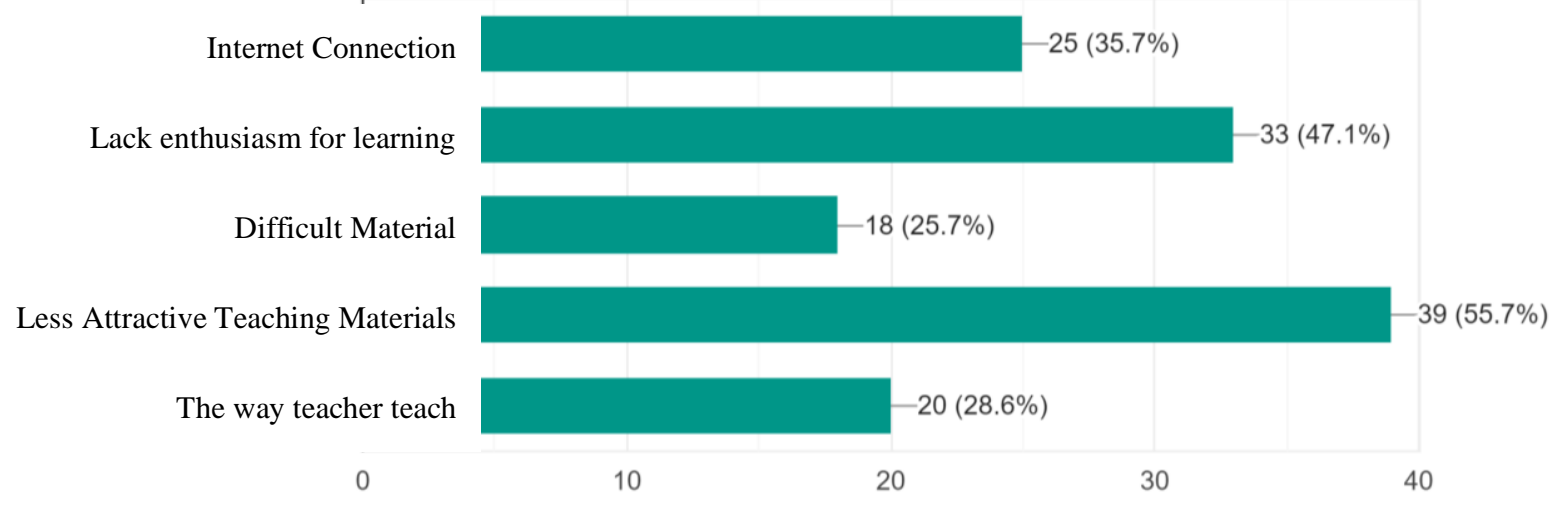

Figure 3. Percentage of obstacles faced by students in science online learning.

Online learning in implementation has some obstacles. Barriers with the largest percentage of $55.7 \%$ are teaching materials that are not clear in learning or less attractive. According to Pavlovic et al (2015) many students object to the implementation of online learning. Next is the sub-indicator of teaching materials. The majority of teachers use teaching materials in the form of books that are difficult for students to understand. According to the subject, the teacher has not facilitated students by using teaching materials that are easy to understand. Mustakim (2020) in his research states that online learning will be more efficient if in its application the teacher uses supporting teaching media other than books, namely social media. Based on the information of one student, their teacher only uses Whatsapp Group to give assignments without any brief apperception of the assigned material. Learning and learning activities are very necessary to be well organized and managed (Wijayanti et al., 2015), including the application of teaching materials in learning. Ultimately, there is 
a greater need for educational institutions to strengthen practice in curricula and the use of innovative teaching techniques and approaches will be essential (Toquero, 2020).

The second obstacle is the lack of enthusiasm for learning, which is $47.1 \%$. This is in line with research from Amalia et al (2020) that one of the obstacles that arise in online learning is the lack of student motivation. Cahyani et al (2020) revealed that the learning motivation of students who took part in online learning in the midst of the Covid-19 pandemic situation decreased. This can be caused by the condition of students' learning while studying at home for a long time, thus making them bored and finally lazy.

The third obstacle is internet connection, which is $35.7 \%$. As in previous research, Sadikin and Hamidah (2020) said that the challenges in online or online learning include the availability of internet services and inadequate quotas due to the purchase of internet data quotas which are quite expensive. Napitupulu (2020) also states that the biggest dissatisfaction with online learning is due to network instability, and students are cited as having network difficulties that interfere with their classes. Networking is an important factor in the online learning environment. Students highlight increasing networking, which caters to online learning classrooms, as an important consideration. In online learning, networking is not only a method for distributing educational materials, but also a means to promote interaction between teachers and students or among students.

The fourth obstacle is the way teachers teach, which is $28.6 \%$. Some students stated that their teacher only gave practice questions and assignments without explaining the material first. Students suggested that online learning be carried out by first changing the way teachers teach, so far when students carry out online learning, there is no material explanation for some subjects, especially science subjects. Students expect the teacher not only to give assignments, but also to provide material explanations and discussions for the tasks that have been done. Online learning is more student centered so that it can bring up responsibility in learning, thus making students more able to grow independence in learning (Handarini and Wulandari, 2020). Students may still feel confused in the learning process, because they need a brief explanation of the material they have to learn. One solution is that teachers must maximize learning media in the form of videos and continue to follow the development or progress of students in participating in online learning (Purwanto et al., 2020).

The next obstacle is difficult material, amounting to $25.7 \%$. Constraints in the form of a lack of understanding of the material will be faced in online learning (Amalia et al., 2020). Full online learning for more than 1 semester resulted in limited interaction between teachers and students, as well as material explanations that were less than optimal. This is in accordance with the findings of Megawanti's research, which states that the obstacle that arises in extending the time to study from home is that it is difficult for students to understand and master the subject matter because the teacher does not explain or the teacher is not clear in his explanation (Megawanti et al., 2020). This is also consistent with the results of Owusu-Fordjour's research that online learning has a negative impact on learning, because many students are not accustomed to effective independent learning. The launched e-learning platform is also a challenge for the majority of students due to limited internet access (Owusu-Fordjour et al., 2020). 


\section{CONCLUSIONS}

Based on the results of research and analysis of reviews, it can be concluded that the obstacle with the largest percentage faced by junior high school students in Nganjuk in science online learning is that the teaching materials used are less attractive. The suggestions that can be considered from these conclusions are using appropriate learning approaches and other alternative media in online-based science learning such as YouTube to make it easier for students to understand learning materials, as well as create interesting science learning content so that it can foster student motivation to take part in math-based learning. on line.

\section{REFERENCES}

Abidin, Z., \& Arizona, K. (2020). Pembelajaran online berbasis proyek salah satu solusi kegiatan belajar mengajar di tengah pandemi covid-19. Jurnal Ilmiah Profesi Pendidikan, 5(1), 6470. https://doi.org/10.29303/jipp.v5i1.111

Adiyanta, F. C. (2019). Hukum dan studi penelitian empiris: Penggunaan metode survey sebagai instrumen penelitian hukum empiris. Administrative Law and Governance Journal, 2(1), 697-709. https://doi.org/10.14710/alj.v2i4.697-709

Ali, L. U. (2018). Pengelolaan pembelajaran IPA ditinjau dari hakikat Sains pada SMP di kabupaten Lombok Timur. Prisma Sains: Jurnal Pengkajian Ilmu dan Pembelajaran Matematika dan IPA IKIP Mataram, 6(2), 103-112. https://doi.org/10.33394/jps.v6i2.1020

Amalia, R. U., Isnaeni, B., Purwati, \& Hanafi, Y. (2020). Constraints analysis of students in online learning of biological materials at SMP Negeri 3 Bantul. Bio Education: The Journal of Science and Biology Education, 5(2), 10-15. https://doi.org/10.31949/be.v5i2.2422.

Arikunto, S. (2010). Prosedur penelitian: Suatu pendekatan praktik (edisi revisi). Rineka Cipta. https:// doi.org/10.1017/CBO9781107415324.0 04

Arnaud, C. H. (2020). Tips for teaching in the time of corona virus. Chemical \& Engineering News.

Cahyani, A., Listiana, I. D., \& Puteri, S. D. L. (2020). Motivasi belajar siswa SMA pada pembelajaran daring di masa pandemi covid-19. IQ (Ilmu Al-Qur'an): Jurnal Pendidikan Islam, 3(01), 123-140. https:// doi.org/10.37542/iq.v3i01.57

Chung, E., Subramaniam, G., \& Dass, L. C. (2020). Online learning readiness among university students in Malaysia amidst COVID-19. Asian Journal of University Education, 16(2), 4658 .

Fauzi, I., \& Khusuma, I. H. S. (2020). Teachers' elementary school in online learning of COVID19 pandemic conditions. Jurnal Iqra': Kajian Ilmu Pendidikan, 5(1), 58-70. https://doi.org/10.25217/ji.v5i1.914

Gilbert, B. (2015). Online learning revealing the benefits and challenges. Education Masters.

Handarini, O. I., \& Wulandari, S. S. (2020). Pembelajaran daring sebagai upaya study from home (SFH) selama pandemi covid 19. Jurnal Pendidikan Administrasi Perkantoran, 8(3), 496-503.

Hung, M., Chou, C., Chen, C., \& Own, Z. (2010). Learner readiness for online learning: Scale development and student perceptions. Computer $\mathcal{E}$ Education, 55(1), 1080-1090. https://doi.org/10.1016/j.compedu.2010.05.004

Landicho, C. J. B. (2021). Changes, challenges, and opportunities in teaching senior high school earth science amidst the covid-19 pandemic. Journal of Learning and Teaching in Digital Age, 6(1), 55-57.

Megawanti, P., Megawati, E., \& Nurkhafifah, S. (2020). Persepsi peserta didik terhadap PJJ pada masa pandemi covid-19. Jurnal Ilmiah Kependidikan, 7(2), 75-82. http://dx.doi.org/10.30998/fjik.v7i2.6411 
Mustakim. (2020). Efektivitas pembelajaran daring menggunakan media online selama pandemi covid-19 pada mata pelajaran matematika the effectiveness of e-learning using online media during the covid-19 pandemic in mathematics. Al Asma: Journal of Islamic Education, 2(1), 1-12. https://doi.org/10.24252/asma.v2i1.13646

Napitupulu, R. M. (2020). Dampak pandemi covid-19 terhadap kepuasan pembelajaran jarak jauh. Jurnal inovasi teknologi pendidikan, 7(1), 23-33. https://doi.org/10.21831/jitp.v7i1.32771.

Onyema, E. M., Eucheria, N. C., Obafemi, F. A., Sen, S., Atonye, F. G., Sharma, A., \& Alsayed, A. O. (2020). Impact of coronavirus pandemic on education. Journal of Education and Practice, 11(13), 108-121. https:// doi.org/10.7176/JEP/11-13-12.

Owusu-Fordjour, C., Koomson, C. K., \& Hanson, D. (2020). The Impact of Covid-19 on Learning - The Perspective of The Ghanaian Student. European Journal of Education Studies, 7(3), 88-101. https://doi.org/10.5281/zenodo.3753586.

Pavlovic, M., Vugdelija, N., \& Kojic, R. (2015). The use of social networks for e-learning improvement. Hellenic Journal of Music Education, and Culture, 6(3), 13-17.

Purwanto, A., Asbari, M., Fahlevi, M., Mufid, A., Agistiawati, E., Cahyono, Y., \& Suryani, P. (2020). Impact of work from home (WFH) on Indonesian teachers performance during the covid-19 pandemic: An exploratory study. International Journal of Advanced Science and Technology, 29(5), 6235-6244.

Rafique, G. M., Mahmood, K., Warraich, N., \& Rehman, S. U. (2021). Readiness for online learning during covid-19 pandemic: A survey of Pakistani LIS students. The Journal of Academic Librarianship, 47(3), 1-10. https://doi.org/10.1016/j.acalib.2021.102346.

Rosdiana, L., Widodo, W., Nurita, T., \& Fauziah, A. N. M. (2018). E-learning task analysis making temporal evolutiongraphics on symptoms of waves and the ability to solve problems. International Conference on Science Education (ICoSEd), 1006(1), 1-9. https://doi.org/10.1088/1742-6596/1006/1/012025.

Rusilowati, A., Kurniawati, L., Nugroho, S. E., \& Widiyatmoko, A. (2016). Developing an instrument of scientific literacy asessment on the cycle theme. International Journal of Environmental \& Science Education, 11(12), 5718-5727.

Sadikin, A., \& Hamidah, A. (2020). Pembelajaran daring di tengah wabah covid-19 (online learning in the middle of the covid-19 pandemic). BIODIK: Jurnal Ilmiah Pendidikan Biologi, 6(1), 214-224. https://doi.org/10.22437/bio.v6i2.9759

Saifuddin, M. F. (2018). E-Learning dalam persepsi mahasiswa. Jurnal VARIDIKA, 29(2), 102109. https://doi.org/10.23917/varidika.v29i2.5637.

Sudjana, N. (2012). Teknik penentuan populasi dan sampel penelitian dan penilaian pendidikan. Bandung: Sinar Baru Algesindo.

Toquero, C. M. (2020). Challenges and opportunities for higher education amid the covid-19 pandemic: The philippine context. Pedagogical Research, 5(4), 1-5. https:// doi.org/10.29333/pr/7947.

UNESCO. (2020). Education: From disruption to recovery. Accessed on 1 August 2021 https://en.unesco.org/covid19/educationresponse

Wijaya, T., Zhou, Y., Purnama, A., \& Hermita, N. (2020). Indonesian students' learning attitude towards online learning during the coronavirus pandemic. Psychology, Evaluation, and Technology in Educational Research, 3(1), 17-25. http://dx.doi.org/10.33292/ petier.v3i1.56.

Wijayanti, W., Zulaeha, I., \& Rustono. (2015). Pengembangan bahan ajar interaktif kompetensi memproduksi teks prosedur kompleks yang bermuatan kesantunan bagi peserta didik kelas X SMA/MA. Seloka: Jurnal Pendidikan Bahasa Dan Sastra Indonesia, 4(2), 94-101. https:// doi.org/10.15294/SELOKA.V4I2.9866 


\footnotetext{
${ }^{*}$ Desy Suryani (Corresponding Author)

Universitas Negeri Surabaya,

Postgraduate Programme, Science Education Study Program

Continuing Program Development, Jl. Unesa Lidah Wetan, Surabaya, East Java, Indonesia

Email: desy.19047@mhs.unesa.ac.id
}

\section{Eko Hariyono}

Universitas Negeri Surabaya,

Postgraduate Programme, Science Education Study Program

Continuing Program Development, Jl. Unesa Lidah Wetan, Surabaya, East Java, Indonesia

Email: ekohariyono@unesa.ac.id

\section{Tjipto Prastowo}

Universitas Negeri Surabaya,

Physics Department

Jl. Ketintang, Gedung C3 Lt 1, Surabaya, East Java, Indonesia

Email: tiiptoprastowo@unesa.ac.id 